\title{
Autoantibodies in the sicca syndrome (primary Sjögren's syndrome).
}

\author{
KEITH B. ELKON, ${ }^{1}$ AZZUDIN E. GHARAVI, ${ }^{1}$ GRAHAM R. V. HUGHES, \\ AND HARALAMPOS M. MOUTSOUPOULOS ${ }^{2}$
}

From the ${ }^{1}$ Rheumatology Unit, Hammersmith Hospital and Royal Postgraduate Medical School, Du Cane Road, London W12, and the ${ }^{2}$ School of Medicine, University of Ioannina, Greece

SUMMARY IgA and IgM rheumatoid factors as well as antibodies to Ro and La were measured in 37 patients with the sicca syndrome and 9 patients with Sjögren's syndrome secondary to rheumatoid arthritis. Positive results were found in $84 \%$ ( $\operatorname{IgA}$ rheumatoid factor), $76 \%$ (IgM rheumatoid factor), $62 \%$ (Ro), and $50 \%$ (La) of patients with the sicca syndrome. There was no significant difference in the frequency of positive results in patients with glandular versus extraglandular disease. Antibodies to La invariably occurred in patients with antibodies to Ro. In addition, patients who were anti-Ro positive also had significantly higher $\operatorname{IgA}(\mathrm{p}<0.05)$ and $\operatorname{IgM}$ $(p<0.01)$ rheumatoid factor activity. Since $81 \%$ of the sicca patients were concordant for 3 of the 4 antibodies tested, production of these autoantibodies appears to be related.

A broad range of autoantibodies are detected in the serum of patients with the sicca syndrome (primary Sjögren's syndrome). ${ }^{1}$ We measured serum $\operatorname{IgA}$ and IgM rheumatoid factors as well as antibodies to Ro (SSA) and La (SSB) in a large series of sicca syndrome (SS) patients to determine the following: (1) the frequency with which these antibodies could be detected in the serum; (2) whether differences exist in autoantibody frequency in patients with disease confined to the exocrine glands (glandular or local SS) compared with patients with systemic features (extraglandular or systemic SS); (3) whether the elevation of each antibody occurs in isolation or is accompanied by increases in other antibodies. In a smaller group of patients with Sjögren's syndrome secondary to rheumatoid arthritis (RA) we compared the frequency of detection of the same autoantibodies.

\section{Materials and methods}

Patients. Thirty-seven patients were diagnosed as having primary SS at the National Institute of Health on the basis of a positive lip biopsy ${ }^{2}$ with keratoconjunctivitis sicca, xerostomia, and recurrent salivary

Accepted for publication 4 July 1983.

Correspondence to Dr K. B. Elkon, Hospital for Special Surgery, 535 East 70th Street, New York, NY 10021, USA. gland enlargement. ${ }^{3}$ The following were classified as extraglandular features of SS: Raynaud's phenomenon, arthralgias, purpura, nephropathy, pneumonitis, vasculitis, myositis, and pseudolymphoma. Nine patients with definite or classical $\mathrm{RA}^{+}$and the sicca complex (histologically confirmed) were included as a separate group.

Rheumatoid factor radioimmunoassay. IgA and IgM rheumatoid factor activity were measured by a solid-phase radioimmunoassay as described previously. ${ }^{5}$ The assay was modified in that human rather than rabbit IgG was used as antigen, incubations were performed at room temperature, and affinity-purified ${ }^{125}$ I-labelled $\mathrm{F}\left(\mathrm{ab}^{\prime}\right)_{2}$ anti- $\mu$ or anti- $\alpha$ were used to detect $\operatorname{IgM}$ and $\operatorname{IgA}$ rheumatoid factors respectively. The results were expresed as percentage $\mathrm{F}\left(\mathrm{ab}^{\prime}\right)_{2}$ anti $-\mu$ or ant $\mathrm{i}-\alpha$ bound. Binding greater than 2 standard deviations above the mean obtained in 20 normal controls was considered positive.

Assay for Ro and La. These antigens were prepared from human spleen and rabbit thymus extract (Pel-Freeze, Arkansas, USA) according to published methods. ${ }^{67}$ Counterimmunoelectrophoresis was performed by the method of Kurata and $\operatorname{Tan}^{7}$ with minor modifications. $^{*}$

\section{Results}

$\lg A$ and $\lg M$ rheumatoid factors. $\operatorname{Ig} \mathrm{A}$ and $\lg \mathrm{M}$ 
rheumatoid factor activity in patients with SS and Sjögren's syndrome (RA) are shown in Fig. 1A and B. Thus $31 / 37(84 \%)$ of SS patients were positive for IgA rheumatoid factor and $28 / 37(76 \%)$ positive for IgM rheumatoid factor. The mean rheumatoid factor activity (expressed as \% $\mathrm{F}\left(\mathrm{ab}^{\prime}\right)_{2}$ bound) for glandular (G) and extraglandular patients (EG) was similar, namely, IgA rheumatoid factor $4 \cdot 2(\mathrm{G})$ and 4.6 (EG), IgM rheumatoid factor $15 \cdot 1$ (G) and $15 \cdot 6$ (EG). The corresponding mean percentage binding for Sjögren's syndrome (RA) was 3.9 (IgA rheumatoid factor) and 18.0 (IgM factor). These values did not differ significantly from the results obtained in the sicca syndrome (Student's $t$ test). While no correlation between $\operatorname{IgA}$ and IgM rheumatoid factor was found in SS (EG) $(r=0.43$, $p>0 \cdot 1$, a weak correlation was found in SS (G) $(\mathrm{r}=0.52, \mathrm{p}<0.05)$.

Antibodies to Ro and La. Antibodies to Ro were found in $23 / 37(62 \%)$ and antibodies to $\mathrm{La}$ in $16 / 37$ $(43 \%)$ of patients with SS. Both antibodies were present in slightly higher frequency in patients with extraglandular features (Ro $69 \%$, La 50\%) compared than in patients with glandular disease (Ro $57 \%$ and $\mathrm{La} \mathrm{38 \% ).} \mathrm{None} \mathrm{of} \mathrm{the} \mathrm{patients} \mathrm{with} \mathrm{Sjög-}$ ren's syndrome (RA) had antibodies to either antigen detected.

All SS patients with antibodies to La also had antibodies to Ro and 16 of $23(70 \%)$ anti-Ro positive patients had antibodies to La. Patients with SS who were anti-Ro positive had significantly higher $\operatorname{IgA}$ $(p<0.05)$ and IgM rheumatoid factor activity $(p<0.001)$ than patients who were anti-Ro negative. Sixteen of $17(94 \%)$ patients with IgM rheumatoid factor activity above $15 \%$ binding had anti-Ro antibodies (Fig. 1) compared with only $7 / 20(35 \%)$ patients with low IgM rheumatoid factor activity ( $<15 \%$ binding) $(p<0.01)$. Thirty patients $(81 \%)$ had concordant results for three of the 4 autoantibodies measured.

\section{Discussion}

The sicca syndrome is a disease characterised by infiltration of exocrine and mucosal glands. ${ }^{1} \mathrm{We}$ recently demonstrated high levels of $\operatorname{Ig}$ A rheumatoid factor in the serum of SS patients ${ }^{5}$ and showed that these antibodies were predominantly polymeric in nature, suggesting a possible mucosal origin. ${ }^{9}$ In the current study of a larger number of SS patients we confirmed the high frequency $(84 \%)$ of serum $\operatorname{IgA}$ rheumatoid factors but found no significant difference in activity in glandular versus extraglandular disease (Fig. 1). IgM rheumatoid factors were detected in $76 \%$ of SS patients, and, although the correlations between $\operatorname{IgA}$ and $\operatorname{IgM}$ rheumatoid factors were weak, the results were concordant in 32/37 $(86 \%)$ of patients.

The frequency of detection of antibodies to the
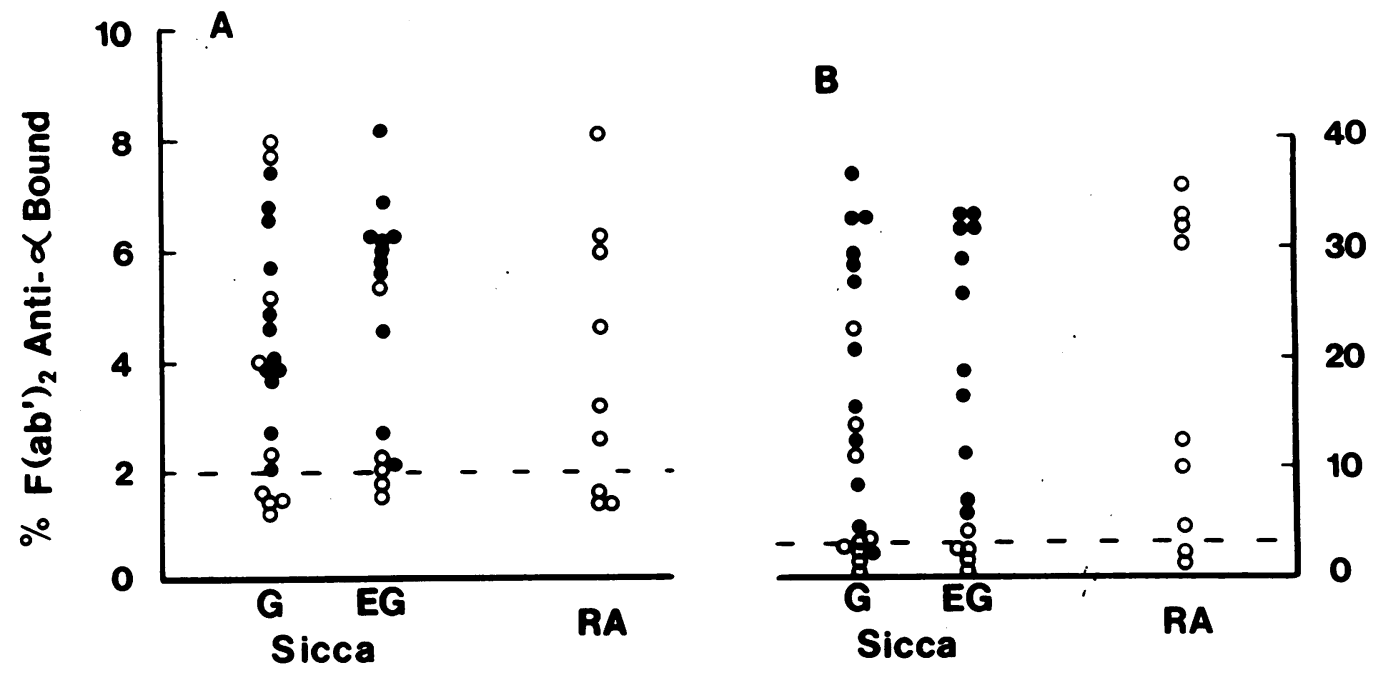

Fig. 1. $\operatorname{IgA}(\mathrm{A})$ and $\operatorname{Ig} M$ (B) rheumatoid factor activity in 37 patients with sicca syndrome either con fined to exocrine glands (G) or with extraglandular manifestations (EG). Rheumatoid factor activity in 9 patients with Sjögren's syndrome secondary to rheumatoid arthritis $(R A)$ are included. Normal ranges are indicated by horizontal dashed lines. Patients with positive or negative tests for anti-Ro antibody are denoted by a closed (O) or open (O) circle respectively. 
saline extractable nuclear antigens Ro $(62 \%)$ and $\mathrm{La}$ $(43 \%)$ were similar to the results reported previously. ${ }^{10} 11$ The lower frequency of detection compared with rheumatoid factor may relate to the lesser sensitivity of counterimmunoelectrophoresis relative to radioimmunoassay. All patients with antibodies to La also had antibodies to Ro. Recently a 'linkage' of these antibodies has been noted in a subset of lupus patients with a low frequency of antibodies to DNA and low frequency of renal disease. ${ }^{12}$ Although a clinical correlation with sicca was not established in the lupus patients, the possibility that these patients had subclinical sicca requires evaluation. Of additional interest in the current study were the findings that both $\operatorname{IgA}(p<0.05)$ and $\operatorname{IgM}(p<0.001)$ rheumatoid factor activity were significantly higher in patients who had antibodies to Ro (Fig. 1) and that $81 \%$ of SS patients had concordant results for 3 of the 4 tests. It seems likely therefore that production of these autoantibodies is related to a common event and/or similar humoral immune response. These results are different from those in Sjögren's syndrome (RA), where significant $\operatorname{IgA}$ and IgM rheumatoid factor activity is detected in the virtual absence of antibodies to Ro or $\mathrm{La}^{10}$ (Fig. 1).

The role of rheumatoid factors and antibodies to $\mathrm{Ro}$ and $\mathrm{La}$ in SS remains uncertain. Although a strong correlation was found between serum rheumatoid factor activity and $\mathrm{Clq}$ binding immune complexes, IgM rheumatoid factor was not identified as a component of the complexes. ${ }^{13}$ Since the circulating immune complexes ${ }^{13}$ as well as the autoantibodies are found as frequently in glandular as in extraglandular sicca syndrome, neither alone can account for the systemic manifestations of the disease.

We gratefully acknowledge technical assistance from C.C. Bunn and B. M. Patel.

\section{References}

1 Moutsoupoulos H M, Chused T M, Mann D L, et al. Sjögren's syndrome (sicca syndrome): current issues. Ann Intern Med 1980; 92: 212-26.

2 Greenspan J S, Daniels T E, Talal N, Sylvester R A. The histopathology of Sjögren's syndrome in labial gland biopsies. Oral Surg 1974; 37: 217-29.

3 Moutsoupoulos H M, Weber B L, Vlagopoulos T P, Chused T M, Decker J. L. Differences in the clinical manifestations of sicca syndrome in the presence and absence of rheumatoid arthritis. Am J Med 1979; 66: 733-6.

4 Ropes M W, Bennet G A, Cobb S, Jacox R. F, Jessar R A. Revision of diagnostic criteria for rheumatoid arthritis. Bull Rheum Dis 1958; 9: 175.

5 Elkon K B, Caeiro F, Gharavi A E, Patel B M, Ferjencik P P, Hughes G R V. Radioimmunoassay profile of antiglobulins in connective tissue diseases: elevated level of $\operatorname{IgA}$ antiglobulin in systemic sicca syndrome. Clin Exp Immunol 1981; 46: 547-56.

6 Clark G, Reichlin M, Tomasi T B. Characterization of a soluble cytoplasmic antigen reactive with sera from patients with systemic lupus erythematosus. J Immunol 1969; 102: 117-22.

7 Kurata N, Tan E M. Identification of antibodies to nuclear acidic antigens by counterimmunoelectrophoresis. Arthritis Rheum 1976; 19: 574-80.

8 Bunn C C, Gharavi A E, Hughes G R V. Antibodies to extractable nuclear antigens in 173 patients with DNA-binding positive SLE: an association between antibodies to RNP and Sm antigens observed by counterimmunoelectrophoresis. J Clin Lab Immunol 1982; 8: 13-7.

9 Elkon K B, Delacroix D L, Gharavi A E, Vaerman J P, Hughes G R V. Immunoglobulin A and polymeric IgA rheumatoid factors in systemic sicca syndrome: partial characterization. $J$ Immunol 1982; 129: 576-81.

10 Alspaugh M A, Talal N, Tan E M. Differentiation and characterization of autoantibodies and their antigens in Sjögren's syndrome. Arthritis Rheum 1976; 19: 216-22.

11 Martinez-Lavin M, Vaughan J H, Tan E M. Autoantibodies and the spectrum of Sjögren's syndrome. Ann Intern Med 1979; 91: 185-90.

12 Wasicek C A, Reichlin M. Clinical and serological differences between systemic lupus erythematosus patients with antibodies to Ro versus patients with antibodies to Ro and La.J Clin Invest 1982; 69: 835-43.

13 Lawley T J, Moutsoupoulos H M, Katz S I, Theofilopoulos A N, Chused T M, Frank M M. Demonstration of circulating immune complexes in Sjögren's syndrome. $J$ Immunol 1981; 123: 1382-7. 